\title{
The Effect of Curing Period on Strength Behaviour of Sand Bentonite Mixes
}

\author{
Tinku Kalita*, Bidisha Borthakur**, Bendangtemsula Imchen***, \\ Bidisha Deka****, Anupriya Goswami***** \\ *(Assistant Professor, Department of Civil Engineering, Royal Group of Institutions, Guwahati-35) \\ ** (Student, Department of Civil Engineering, Royal Group of Institutions, Guwahati-35) \\ *** (Student, Department of Civil Engineering, Royal Group of Institutions, Guwahati-35) \\ **** (Student, Department of Civil Engineering, Royal Group of Institutions, Guwahati-35) \\ ***** (Student, Department of Civil Engineering, Royal Group of Institutions, Guwahati-35) \\ Corresponding Author: Tinku Kalita
}

\begin{abstract}
A landfill is a secured engineered pit in the ground into which the wastes are dumped. Proper landfill liners need to be used to avoid any hydraulic connections between waste and surrounding environment. These liners can be created of different materials of which sand-bentonite mixtures are attracting greater attention. The sand bentonite mixture is a mixture of two different materials in terms of their particle size and chemical activity to produce a material with low hydraulic conductivity, low compressibility and sufficient strength. Low hydraulic conductivity of the mixture is due to the ability of bentonite particles to swell and fill the voids between the sand particles and whereas sand framework provides low compressibility. In this work, $80 \%$ sand and $20 \%$ bentonite were taken for the sand-bentonite mixture, on which various preliminary tests and secondary tests were carried out to study the properties of the mixture. The Optimum Moisture Content (OMC) and Maximum Dry Density (MDD) were determined by Standard Proctor Test. Variation of unconfined compressive strength with curing period as well as with the water content on sand-bentonite mixture were obtained from the results of the tests performed in order to get the optimum curing period and water content. Hence, a suggestion can be made as to when the maximum Unconfined Compressive Strength (UCS) will occur at a particular curing period.

Keywords: bentonite, curing period, Maximum Dry Density (MDD), Optimum Moisture Content (OMC), Unconfined Compressive Strength (UCS).
\end{abstract}

Date of acceptance: 15-07-2017

\section{INTRODUCTION}

Landfilling is one of the most efficient methods of proper and safe disposal of industrial, municipal and hazardous wastes. Low-permeable barriers such as liners are a part of landfills, which minimize the movement of leachate to surrounding environment and groundwater. Locally available compacted clays are widely used as liners because of their low cost and high contaminant retention capacity. However, in the absence of locally available natural clays, compacted mixtures of expansive soil such as bentonite and sand have been widely used as contaminant barriers. For a material being used as a landfill liner would depend on its low hydraulic conductivity and high contaminant retention capacity. Sufficient strength and low compressibility are also requisite criteria. A well designed landfill can effectively reduce the harmful effects of leachate on the environment. However, care should be taken so that the surrounding soil and water does not get negatively affected due to the wastes dumped in the landfill. This can be achieved by using proper landfill liner. A landfill liner is designed as a very low permeable barrier, which is put under engineered landfill sites. The landfill liner obstructs the flow of leachate, and its toxic material, into the underlying aquifers or its nearby water bodies, before it spoils the local water. Sandbentonite mixture creates an impermeable zone because bentonite is impermeable and has high retention capacity of water. Komine.H et al 2004 [1] found that the sodium bentonite closely concurred with the experimental values. Therefore sodium bentonite is planned for use in radioactive waste disposal projects. Khan.F.S et al 2014 [2] found that the use of inert material is suggested as it is cost effective and also helps to increase shear strength. Durukan. S et al 2003 [3] showed that the bentoniteembedded zeolites (BEZ) with different bentonite content were developed for possible use as barrier material, as an alternative to bentonite-embedded 
sand (BES). Permeability tests on bentoniteembedded zeolites with $10 \%$ and $20 \%$ bentonite content show that the permeability of both mixtures are less than $1 \times 10^{-9} \mathrm{~m} / \mathrm{sec}$ which meets the common regulatory requirements. In this context an attempted has been made to judge the strength of bentonitesand mixes with different curing period.

\section{MATERIAL USED}

Bentonite is highly expansive clay that has an ability to swell when dispersed in water, which is used in construction works mainly in excavation. In this project, the bentonite powder was obtained by Neelkanth manufacturer. The mixture of sand and bentonite possesses very low permeability as the bentonite has the ability to swell upto $400 \%$ and then fill the voids between the sand particles. Preliminary tests were carried out to study the various properties of the bentonite such as liquid limit, plastic limit, plasticity index, specific gravity and free swell index. Locally available samples of sand were used in this study. The sand is classified as SP as per the Unified Soil Classification System (USCS) classification (IS 1970). The specific gravity of sand is 2.62. The secondary tests were carried out using sand-bentonite mixture, with $80 \%$ sand and $20 \%$ bentonite. Standard proctor test was conducted to find out the optimum moisture content (OMC) and maximum dry density (MDD) of the sand-bentonite mixture. Unconfined compressive strength test were conducted on the samples after the curing period of 1 day, 3 days, 7 days, 14 days and 28 days.

\section{EXPERIMENTAL RESULT}

Preliminary tests were conducted on sodium bentonite to determine the various properties like liquid limit, plastic limit, plasticity index, specific gravity and free swell index. IS-2720 (Part 5)-1985 was used to determine the liquid limit of bentonite by Casagrande apparatus. IS-2720 (Part5)-1985 has been used to determine the plastic limit of bentonite. To determine free swell index of bentonite clay, IS-2720 (Part-40)-1977 has been used. The results of the tests are as shown in Table 1.

Table 3: Results of unconfined compressive strength test

\begin{tabular}{|c|c|c|c|c|c|c|c|c|c|c|}
\hline Curing & \multicolumn{2}{|c|}{ Day 1} & \multicolumn{2}{|c|}{ Day 3} & \multicolumn{2}{|c|}{ Day 7} & \multicolumn{2}{|c|}{ Day 14} & \multicolumn{2}{|c|}{ Day 28} \\
\hline $\begin{array}{c}\text { Water } \\
\text { content }\end{array}$ & $\begin{array}{c}\mathrm{UCS} \\
\left(\mathrm{kN} / \mathrm{m}^{2}\right)\end{array}$ & Strain & $\begin{array}{c}\mathrm{UCS} \\
\left(\mathrm{kN} / \mathrm{m}^{2}\right)\end{array}$ & Strain & $\begin{array}{c}\mathrm{UCS} \\
\left(\mathbf{k N} / \mathrm{m}^{2}\right)\end{array}$ & Strain & $\begin{array}{c}\mathrm{UCS} \\
\left(\mathrm{kN} / \mathrm{m}^{2}\right)\end{array}$ & Strain & $\begin{array}{c}\mathrm{UCS} \\
\left(\mathrm{kN} / \mathrm{m}^{2}\right)\end{array}$ & Strain \\
\hline OMC-5\% & 91.74 & 0.0412 & 101.27 & 0.0645 & 127.31 & 0.0714 & 137.06 & 0.0785 & 94.34 & 0.0551 \\
\hline OMC-3\% & 94.33 & 0.0514 & 107.35 & 0.0701 & 126.44 & 0.0901 & 141.065 & 0.0974 & 110.45 & 0.0654 \\
\hline OMC & 99.45 & 0.0637 & 110.21 & 0.0742 & 127.66 & 0.0947 & 135.44 & 0.105 & 107.55 & 0.0645 \\
\hline $\mathrm{OMC}+3 \%$ & 87.56 & 0.077 & 104.65 & 0.0774 & 112.35 & 0.0996 & 124.65 & 0.113 & 94.65 & 0.077 \\
\hline OMC $+5 \%$ & 67.29 & 0.0912 & 70.83 & 0.0971 & 89.17 & 0.102 & 91.3 & 0.124 & 83.34 & 0.055 \\
\hline
\end{tabular}
2720 (Part 7)-1980. Result of standard proctor test has been shown in Table 2 .

Unconfined compressive strength test were conducted on samples of sand- bentonite mixtures ( $80 \%$ sand and $20 \%$ bentonite) with water content of $\mathrm{OMC}-5 \%$, OMC-3\%, OMC, OMC $+3 \%$ and $\mathrm{C}+5 \%$ for a curing period of 1 day, 3 days, 7 days and 28 days. These tests were imum unconfined compressive strength at what Table 3 .

\begin{tabular}{|c|c|c|c|c|c|}
\hline $\begin{array}{c}\text { Table 1: Properties of bentonite } \\
\text { s }\end{array}$ & $\begin{array}{c}\text { Liquid } \\
\text { limit }\end{array}$ & $\begin{array}{c}\text { Plastic } \\
\text { limit }\end{array}$ & $\begin{array}{c}\text { Plasticity } \\
\text { index }\end{array}$ & $\begin{array}{c}\text { Speci } \\
\text { fic } \\
\text { gravit } \\
\text { y }\end{array}$ & $\begin{array}{c}\text { Free } \\
\text { swellin } \\
\text { g index }\end{array}$ \\
\hline $\begin{array}{c}\text { Bentonit } \\
\text { e }\end{array}$ & $175 \%$ & $46 \%$ & $129 \%$ & 2.69 & $400 \%$ \\
\hline
\end{tabular}

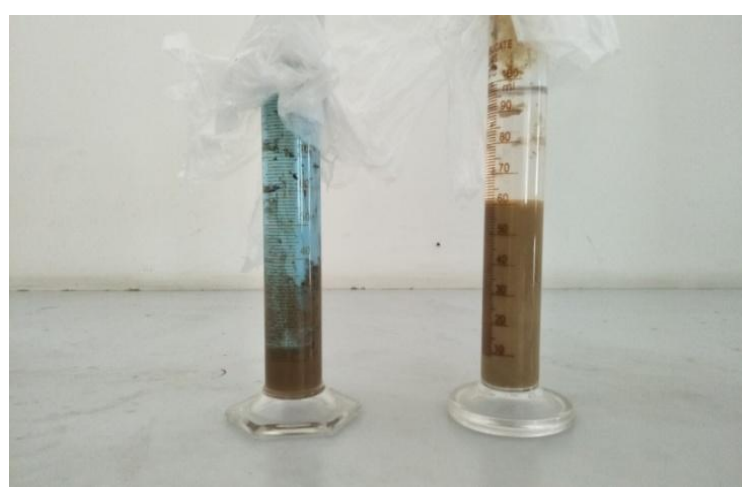

Table 2: Proctor test results for Sand-bentonite mixture with $20 \%$ bentonite and $80 \%$ sand

\begin{tabular}{|c|c|c|}
\hline Properties & OMC & MDD \\
\hline $\begin{array}{c}\text { Sand: bentonite } \\
(80: 20)\end{array}$ & $16.5 \%$ & $1.82 \mathrm{~g} / \mathrm{cc}$ \\
\hline
\end{tabular}




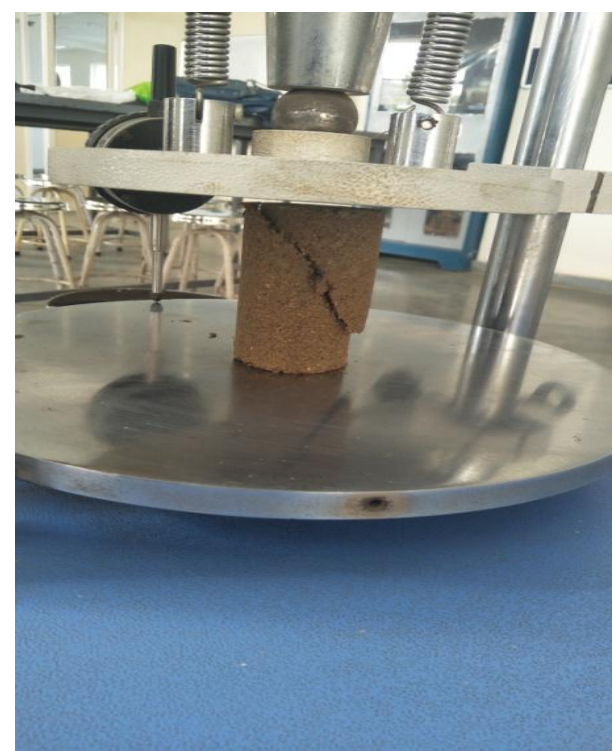

Fig. 2 Failure of sample in UCS test

\section{EXPERIMENTAL OBSERVATION}

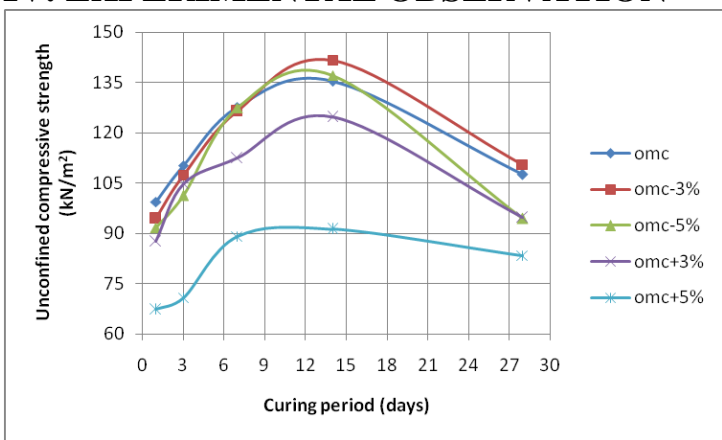

Fig.3 Variation of UCS with curing period

From Fig.3, it can be seen that the maximum unconfined compressive strength is obtained for the curing period of 14 days for all the samples with different water contents. Sample with water content OMC-3\% gave the maximum UCS at day 14.

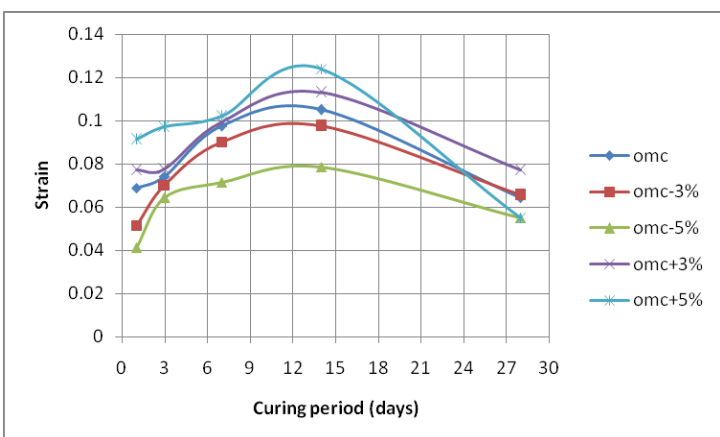

Fig.4 Variation of strain with curing period

From Fig. 4 it can be seen that the strain for all the samples increases up to 14 days and then decreases. It can also be observed that as water content increases for a particular sand-bentonite mixture, the failure occurs at high strain rate which shows that the samples failure behaviour changes from brittle to ductile.

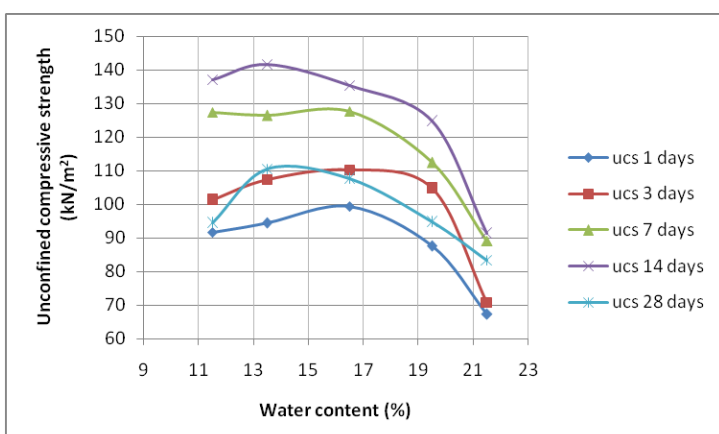

Fig.5 Variation of unconfined compressive strength with water content

From Fig.5 it can be seen that maximum unconfined compressive strength is obtained at 14 days curing period and minimum unconfined compressive strength at 1 day curing period. Water content OMC-3\% gives maximum strength at day 14 curing period.

\section{CONCLUSION}

The following salient observation is obtained from this study:

- Figure 3 shows the variation of unconfined compressive strength with curing period, the peak value is achieved at a curing period of 14 days which means that the strength of the sample is highest at day 14 for all the water contents (OMC-5\%, OMC-3\%, OMC, $\mathrm{OMC}+3 \%, \mathrm{OMC}+5 \%)$.

- Figure 4 shows the variation of strain with curing period, it can be observed that the strain of the samples increases upto 14 days of curing period and then decreases, also it can be observed that as the water content increases the strain value increases which shows that the failure pattern of sample changes from brittle to ductile.

- Hence it can be concluded that maximum strength is found at OMC-3\% for 14 days curing period. It is found that the strength for OMC-3\% increases by $4.13 \%$ as compared to $\mathrm{OMC}$ for curing period of 14 days. 


\section{REFERENCES}

[1] Hideo Komine, Simplified evaluation on hydraulic conductivities of sand-bentonite mixture backfill, Department of Urban and Civil Engineering, Ibaraki University, 4-121 Nakanarusawa-cho, Hitachi, Ibaraki, 3168511, Japan

[2] F.S. Khan, S. Azam, M. Eshwaraiah Raghunandan, $\mathrm{R}$ Clark Compressive Strength of Compacted Clay-Sand Mixes Advances in Materials Science and Engineering Hindawi Publishing Corporation Volume 2014, Article ID 921815, 1-6

[3] A Kaya, S Durukan Utilization of bentonite-embedded zeolite as clay liner Applied clay science, 25, 83-91.

[4] Studds, P.G., Stewart, D.I., Cousens, T.W., 1998. The effects of salt solutions on the properties of bentonite and sand mixtures. Clay Miner, 33, 651-660.

[5] Mollins, L.H., Stewart, D.I., Cousens, T.W., 1996. Predicting the properties of bentonite and sand mixtures. Clay Miner, $31,243-252$.

[6] Komine, H., and Ogata, N. (1996). Prediction for swelling characteristics of compacted bentonite. Can. Geotech. J., 33(1), 11-22.

[7] Komine, H., Ogata, N., 1999. Experimental study on swelling characteristics of sandbentonite mixture for nuclear waste disposal. Soils and Foundations 39 (2), 8397.

[8] IS: 2720 (Part 5)-1985- Methods of tests for soil: "Determination of soil for liquid and plastic limits"

[9] IS: 2720 (Part 40)-1985-Methods of tests for soils: Determination of free soil index of soil

[10] IS: 2720 (Part 7)-1980- Methods of tests for soils: Determination of water content- dry density relation using light compaction (second revision)

[11] IS: 2720 (Part 10)-1991- Methods of tests for soils: Determination of unconfined compressive strength (second revision)
[12] A. Shafiee, H. R. Tavakoli, and M. K. Jafari, Undrained behavior of compacted sand-clay mixtures under monotonic loading paths, Journal of Applied Sciences, vol. 8, no. 18, pp. 3108-3118, 2008.

[13] Komine, H., Ogata, N., 1994. Experimental study on swelling characteristics of compacted bentonite. Canadian Geotechnical Journal 31, 478- 490.

[14] K. S. Prakasha and V. S. Chandrasekaran, Behavior of marine sand-clay mixtures under static and cyclic triaxial shear, Journal of Geotechnical and Geoenvironmental Engineering, vol. 131, no. 2, pp. 213-222, 2005.

[15] B. Wiebe, J. Graham, G. X. Tang, and D. Dixon, Influence of pressure, saturation, and temperature on the behaviour of unsaturated sand-bentonite, Canadian Geotechnical Journal, vol. 35, no. 2, pp. 194-205, 1998.

[16] R.D. Holtz, W.D. Kovacs, and T. C. Sheahan, An Introduction to Geotechnical Engineering (Prentice Hall, Englewood Cliffs, NJ, USA, 2011.)

[17] C. E. Mullins and K. P. Panayiotopoulos, The strength of unsaturated mixtures of sand and kaolin and the concept of effective stress, Journal of Soil Science, vol. 35, no. 3, pp. 459-468, 1984.

[18] Sharma, D. H., and Reddy, R. K. (2004). Geoenvironmental engineering: Site remediation, waste containment and emerging waste management technologies, Wiley, New York.

[19] Daniel, D. E., and Wu, Y. (1993). Compacted clay liners and covers for arid sites. J. Geotech. Eng., 119(2), 223-237.

[20] Daniel, D. E. (1984). Predicting hydraulic conductivity of clay liners. J. Geotech. Eng., 110(4), 465-478.

[21] IS: 2720 (Part 3/section 2) (1980), Methods of Test for Soils: Determination of Specific Gravity, Fine, Medium and Coarse Grained Soils, Bureau of Indian Standards, New Delhi, India.

International Journal of Engineering Research and Applications (IJERA) is UGC approved Journal with Sl. No. 4525, Journal no. 47088. Indexed in Cross Ref, Index Copernicus (ICV 80.82), NASA, Ads, Researcher Id Thomson Reuters, DOAJ.

Tinku Kalita. "The Effect of Curing Period on Strength Behaviour of Sand Bentonite Mixes." International Journal of Engineering Research and Applications (IJERA) 7.7 (2017): 51-54. 